TONG Yan, WANG Huacheng

\title{
Related party transactions, benefits of control and earnings quality
}

\author{
(C) Higher Education Press and Springer-Verlag 2008
}

\begin{abstract}
Controlling shareholders pursue benefits of control (private benefits and shared benefits) via related party transactions, which result in different levels of earnings quality. Using data from all A-share listed companies in Shenzhen and Shanghai stock markets in the year 2001 and 2002, we found that when the share ratio of controlling shareholder is less than $50 \%$, they prefer pursuing private benefits of control via related party transactions, giving rise to deterioration in earnings quality. By comparison, when the share ratio is more than $50 \%$, controlling shareholders prefer pursing shared benefits of control through related party transactions, which improve earnings quality as a result.
\end{abstract}

Keywords related party transactions, benefits of control, earnings quality, controlling shareholders

摘要 控股股东通常使用关联交易追求控制权收益(包括私有收益和共享收益)。在 不同控制权收益驱使下, 关联交易对盈余质量的影响也完全不同, 使用 2001 及 2002 年中国上市公司的数据检验发现, 当控股股东持股在 $50 \%$ 及以下时, 更多通过关联 交易追求控制权私有收益, 结果降低了盈余质量; 而当控股股东持股超过 $50 \%$ 时, 偏好通过关联交易获取控制权共享收益, 最终提高了盈余质量。

关键词 关联交易, 控制权收益, 盈余质量, 控股股东

Translated and revised from Kuaiji yanjiu 会计研究 (Accounting Research), 2007, (4): 60-69

TONG Yan $(\bowtie)$

School of Management and Economics, Beijing Institute of Technology, Beijing 100081, China

E-mail: tongyan@bit.edu.cn

WANG Huacheng

School of Business, Renmin University of China, Beijing 100872, China

E-mail: huacheng2001@263.net 


\section{Introduction}

Enron went bankrupt. KMK and Mailyard (two Chinese listed companies) became cash machines for their block holders. In these cases we could find controlling shareholders who always use related party transactions to tunnel listed companies. Controlling shareholders transfer wealth to related companies by group-related transactions(Chang, 2003; Jian and Wong, 2004), which deteriorate earnings quality (Wang and Tong, 2006).

According to prior literature, Chinese economic institutions, legal system and corporate structure are vulnerable to related party transactions (Jian and Wong, 2004), which are used by controlling shareholders to transfer corporate wealth and expropriate minority shareholders (Yu and Xia, 2004). Normal related party transactions, however, could reduce transaction costs and improve efficiency (Coase, 1937).

Then, how to evaluate related party transactions in Chinese capital market? This paper classifies related party transactions according to the possibility of obtaining different benefits of control by controlling shareholders: when private benefits of control are prevailing, related party transactions will deteriorate earnings quality due to the unfairness; when shared benefits of control preponderate over private benefits of control, related party transactions are often normal and will improve earnings quality accordingly.

\section{Literature review}

\subsection{Controlling shareholders and related party transactions}

As a rule, controlling shareholders have dominant control over corporate decisions, including making decisions of related party transactions. Cheung et al. (2004) examined a sample of 375 cases of "connected transactions" between Hong Kong listed companies and their controlling shareholders during 1998-2000. They found that excess returns both at the initial announcement of the connected transactions and during the 12-month period following the announcement are significantly negatively related to the percentage of ownership by the controlling shareholders and to proxies for information disclosure. The likelihood of occurrence of connected transactions is even higher for some firms when their ultimate controlling shareholders are from the mainland of China. Li et al. (2004) investigated the embezzlement of listed company's funds by controlling shareholders in China. Based on the data about Chinese listed companies over the period of 2000-2003, they found an inverted-U-shaped 
relationship between the embezzlement of list company's funds and the share ratio of the largest shareholder. Yu and Xia (2004) reported that firms with controlling shareholder have more related party transactions than firms without controlling shareholder based on their empirical study during 1999-2001. They thus suggested that controlling shareholders do transfer firm's resources and expropriate minority shareholders by means of related party transactions. According to Chen and Wang (2005), the amount of money transferred and the likelihood of occurrence of related party transactions between the largest shareholder's group and the listed company are positively correlated with the share ratio of the largest shareholder. An increase in the number of shareholders with share ratios of more than $10 \%$ reduces the amount of money transferred and the likelihood of occurrence of related party transactions. In addition, it was also found that the higher balance among controlling shareholders, the less likely related party transactions occur, and the smaller the amount of money transferred.

\subsection{Related party transactions and earnings quality}

Gordon and Henry (2003) found out that earnings management is associated with certain types of related party transactions, such as loans to related parties for reasons other than home and stock purchases. Jian and Wong (2004) provided large sample evidence showing that the corporate structure, economic institutions and legal system in China are vulnerable to related party transactions. They found that when a listed company under a big corporate group is facing delisting or has a strong desire for issuing new shares, large scale of abnormal related party sales usually occur within the group. With cases in the capital market, Huang (2001) illustrated that wealth transfer influence earnings quality directly. Hong and Fang (2005) revealed that there is an inverted-U-shaped relation between the value relevance of earnings quality and related party sales.

As the above literature review shows that controlling shareholders influence related party transactions and the latter in turn shape earnings quality to some extent. But there is still one question which remains unanswered-is earnings quality affected during the process of controlling shareholders pursuing benefits of control through related party transactions? This paper attempts to probe into that in what ways do controlling shareholders influence the earnings quality. More specifically, we want to explore the relationship between related party transactions, as driven by different motivations for benefits of control and earnings quality. 


\section{The effects of related party transactions on earnings quality}

\subsection{Theory analysis}

An important purpose of controlling shareholders' related party transactions is to obtain benefits of control including private benefits ${ }^{1}$ and shared benefits. ${ }^{2}$ The functions of these two kinds of benefits vary with the percentage of shares held by controlling shareholders. When the share ratio is low, controlling shareholders prefer private benefits. When the ratio exceeds the limit line, however, controlling shareholders are apt to obtain shared benefits of control. In doing so, related party transactions could be used by controlling shareholders to obtain private or shared benefits. But as shown in Fig.1, related party transactions pursuing different benefits of control may have varied effects on earnings quality. More specifically, related party transactions are used for acquiring different benefits of control and earnings quality will either be deteriorated or improved accordingly (Fig.1).

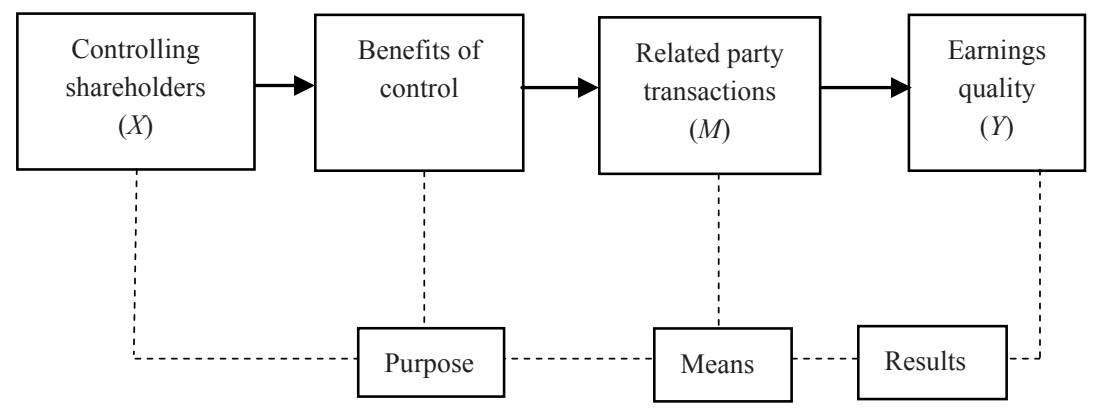

Fig. 1 Relationship among controlling shareholders, related party transactions and earnings quality

\footnotetext{
${ }^{1}$ Dyck and Zingales (2004) defined private benefits of control as some value, whatever the source, not shared among all the shareholders in proportion of the shares owned, but enjoyed exclusively by the party in control.

${ }^{2}$ The shared benefits of control arise from the substantial collocation of decision rights and wealth effects that come with large-block ownership. As the ownership stake of a blockholder increases, ceteris paribus, he has a greater incentive to increase firm value (Holderness, 2003), which could be shared by minority shareholders.
} 


\subsubsection{Related party transactions driven by private benefits}

Private benefits of control are values enjoyed exclusively by the party in control ${ }^{3}$, which is not shared among all the shareholders (or other market participants) in proportion of the shares owned (or other corresponding rights and duties) ${ }^{4}$. When the controlling shareholders' share ratio is low, to pursue private benefits by means of expropriating the interests of minority shareholders is a better choice for controlling shareholders than to pursue shared benefits. Controlling shareholders could transfer wealth or get special benefits by self-dealing transactions between the controlling shareholders and companies they controlled (Gilson and Gordon, 2003). During this process, controlling shareholders have strong incentive to manipulate the financial reports to hide the private benefits of control they obtained and the real performance of the company by various financial behaviors (e.g. related party transactions).

\subsubsection{Related party transactions driven by shared benefits}

At the same time, there are also shared benefits (Shleifer and Vishny, 1986; Mikkelson and Ruback, 1985). When the share ratio of controlling shareholders reaches a certain level, they have a strong motivation to enhance the enterprise value (Holderness, 2003). In doing so, related party transactions are always adopted as a useful method for they can reduce transaction costs and improve efficiency. Under such circumstances, related party transactions are regarded as fair and enterprise-value-maximum-oriented and will not affect earnings quality negatively. In China, however, the capital market and corresponding corporate governance system are far from being mature. The value of shared benefits has not been fully confirmed in the Chinese context. There are even some extreme examples such as 999 Pharmacy and Jiuguijiu Wine (Sun and Huang, 1999), in which the share ratios of controlling shareholders are over $60 \%$. Yet the controlling shareholders in these companies still indulged in tunneling their companies. What about other Chinese listed companies? In the present article, we attempt to explore into the interrelationship among related party transactions, benefits of control and earnings quality in Chinese listed companies.

\footnotetext{
${ }^{3}$ The theoretical literature often identifies private benefits of control as the psychic value enjoyed by some shareholders due to control right (Harris and Raviv, 1988; Aghion and Bolton, 1992). Although this is certainly a factor in some cases, it is hard to explain resources consumption and funds transfer in large amount.

${ }^{4}$ This concept was presented by Dyck and Zingales (2004), but they didn't consider other market participants except shareholders.
} 


\subsection{Hypothesis development}

To summarize, controlling shareholders pursue benefits of control via related party transactions which result in different levels of earnings quality (Fig.1). When the share ratio is low, controlling shareholders prefer obtaining private benefits by means of unfair related party transactions which lead to low earnings quality. While the ratio is high, controlling shareholders pursue shared benefits instead of private benefits. The comparatively fair related party transactions under such circumstances are beneficial to the improvement of earnings quality. In Fig.1, the share ratio of controlling shareholders $(X)$ exerts an impact on earnings quality $(Y)$ via related party transactions $(M)$.

Mediation tests ${ }^{5}$ are widely used in scientific studies such as management, psychology, sociology, etc (Baron and Kenny, 1986; Shaver, 2005). A variable could be called a mediator when it meets the following three conditions: first, independent $X$ significantly relates to dependent $Y$; second, independent $X$ significantly relates to mediator $M$; third, when $X$ and $M$ both are independents in the model, the previously significant relationship between the independent and dependent variables disappear. Then, we could say a strongest mediation occurs and $M$ is a single, dominate mediator. Of course, this kind of mediator is rare in humanities and social sciences. What we often find is that the relationship between the independent and dependent is still significant but becomes weaker than that of in the first step. This result indicates the $M$ acted as a partial mediator between $X$ and $Y$. There are a number of statistical methods we can use to measure the change of effect an independent variable on a dependent variable. Each of these methods has its own advantages and disadvantages (MacKinnon et al., 2002). We need to choose from them in accordance with the specific study purpose.

Based on the discussion of mediating variable, we propose three basic hypotheses as below:

H1: When the share ratio is low, controlling shareholder's share ratio is negatively related to earnings quality; when the ratio is high, the relationship is positive.

H2: There is a positive relationship between the share ratio of controlling shareholders and related party transactions.

H3: When the share ratio is low, related party transactions are used to obtain

${ }^{5}$ Some scholars questioned this testing method (Shaver, 2005). Generally speaking, simultaneous equations and 2SLS can be adopted to solve the existing problems of our method. But in this paper, we used dummy dependent variable, and made the product of the two independents as the proxy of other variables' impact on earnings quality, which limits the adoption of other testing methods. Considering the method of mediation test is widely used and accepted, we still choose this method in the present study. 
private benefits of control, resulting in lowered earnings quality; when the ratio is high, related party transactions serve for shared benefits, resulting in improved earnings quality.

\section{Concepts and models}

\subsection{Concepts}

\subsubsection{Related party transactions}

In this paper, we only consider those related party transactions which are directly related to the interests of controlling shareholders and thus are under direct control of controlling shareholders. That is to say, related party transactions are defined as the transactions between listed companies and controlling shareholders (corporations or individuals) and other entities controlled by the controlling shareholders. We used a dummy variable as the proxy of related party transactions occurrence (if a listed company involves in related party transaction, the dummy variable $=1$, otherwise, it $=0$ ), regardless of the frequency, amounts, benefits transferred and ways of these related party transactions.

\subsubsection{Controlling shareholders}

In most cases, the controlling shareholder in a company is the largest shareholder in Chinese capital market. Hence we use the share ratio of the largest shareholder as the proxy for the power of controlling shareholder.

\subsubsection{Earnings quality}

This paper uses value relevance based on market returns to measure earnings quality, which is defined as the ability of accounting earnings to explain and forecast market returns. The main method in the research of value relevance is computing the earnings response coefficient (ERC) (Hayn, 1995). Drawing on Fan and Wong's (2002) study procedure, we multiplied earnings by the share ratio of controlling shareholders and related party transactions and entered the products into the basic ERC model to measure the effects of those variables on basic ERC.

\subsection{Models}

Based on basic ERC model, mediation test and controlled variables in previous 
literature, we build models below:

$$
\begin{aligned}
R_{i, t}= & \alpha_{0}+\beta_{1} E P S_{i, t} / P_{i, t-1}+\lambda E P S_{i, t} / P_{i, t-1} * C S_{i, t-1}+\delta_{1} \text { Lev }_{i, t} \\
+ & \delta_{2} \text { Size }_{i, t}+\delta_{3} \text { Beta }_{i, t}+\delta_{4} Q_{i, t}+\delta_{5} \text { Year }+\delta_{6} I N D+\varepsilon_{1} \\
R P T_{i, t}= & \alpha_{1}+a C S_{i, t-1}+a_{1} \text { Second }_{i, t-1}+a_{2} \text { Third }_{i, t-1}+a_{3} \text { Year } \\
& +a_{4} I N D+\varepsilon_{2} \\
R_{i, t}= & \alpha_{2}+\beta_{2} E \text { PS }_{i, t} / P_{i, t-1}+\lambda^{\prime} E P S_{i, t} / P_{i, t-1} * C S_{i, t-1} \\
+ & b E P S_{i, t} / P_{i, t-1} * R P T_{i, t}+\delta_{7} \text { Lev }_{i, t}+\delta_{8} \text { Size }_{i, t} \\
+ & \delta_{9} \text { Beta }_{i, t}+\delta_{10} Q_{i, t}+\delta_{11} \text { Year }+\delta_{12} I N D+\varepsilon_{3}
\end{aligned}
$$

These three models are corresponding to the above three hypotheses respectively.

Model 1 reflects the impact of controlling shareholders on earnings quality. $\beta_{1}$ is basic ERC, $\lambda$ represents the impact of share ratio of controlling shareholders on basic ERC. According to hypothesis $1, \lambda$ is significantly negative when the ratio is below the dividing line, positive when the ratio exceeds the line.

Model 2 tests the relationship between controlling shareholders and related party transactions. The likelihood of related party transactions is increasing along with the increase of the share ratio of controlling shareholders. $a$ should be significantly positive.

Model 3 focuses on the relationship among controlling shareholders, related party transactions and earnings quality. $\beta_{2}$ is basic ERC, $\lambda^{\prime}$ represents the impact of the share ratio on basic ERC after considering related party transactions. $b$ evaluates the impact of related party transactions on basic ERC. If a mediation effect exists, according to hypothesis $3, \lambda^{\prime}$ is significantly less than $\lambda, \lambda^{\prime}$ and $b$ are significantly negative below the dividing line of the share ratio, positive when the ratio exceeds the line.

Table 1 shows the variable definitions:

Table 1 Variable description

\begin{tabular}{ll}
\hline$R_{i, t}$ & $\begin{array}{c}\text { Market returns of corporation } i \text { in period } t \text {, adjusted closing price } \\
\text { (considering dividends) on Apr. } 30 \text { in year } t+1 \text { divided by what in year } t\end{array}$ \\
$E P S_{i, t}$ & Net earnings per share of corporation $i$ at the end of period $t$ \\
$P_{i, t-1}$ & $\begin{array}{c}\text { Adjusted closing price considering dividend paying and placing stocks of } \\
\text { corporation } i \text { on Apr. } 30 \text { in year } t-1\end{array}$ \\
\hline
\end{tabular}

(To be Continued) 


\begin{tabular}{|c|c|}
\hline & (Continued) \\
\hline$C S_{i, t-1}$ & $\begin{array}{l}\text { The share ratio of the largest shareholder of corporation } i \text { at the end of } \\
\text { period } t-1 \text {. }\end{array}$ \\
\hline $\operatorname{Lev}_{i, t}$ & Debt ratio of corporation $i$ at the end of period $t$ \\
\hline Size $_{i, t}$ & Logarithm of total assets of corporation $i$ at the end of period $t$ \\
\hline Beta $_{i, t}$ & Beta of corporation $i$ at the end of period $t$ \\
\hline$Q_{i, t}$ & $\begin{array}{l}\text { Total market value (considering Non-Circulating Stocks) divided by } \\
\text { book value of corporation } i \text { at the end of period } t\end{array}$ \\
\hline$R P T_{i, t}$ & $\begin{array}{l}\text { If the related party transactions happen or not, } 1 \text { for yes and } 0 \text { for no in } \\
\text { period } t\end{array}$ \\
\hline Second $_{i, t-1}$ & $\begin{array}{l}\text { The share ratio of the second largest shareholder of corporation } i \text { at the } \\
\text { end of period } t-1\end{array}$ \\
\hline Third $_{i, t-1}$ & $\begin{array}{l}\text { The share ratio of the third largest shareholder of corporation } i \text { at the end } \\
\text { of period } t-1\end{array}$ \\
\hline Year & Data period \\
\hline$I N D$ & Corporate industry \\
\hline
\end{tabular}

\section{Empirical tests}

\subsection{Sample and descriptive statistics}

The sample consists of data in year 2001, 2002 of listed companies in Shenzhen and Shanghai A-share markets from CCER database of Beijing Sinofin Company. Sample of listed companies in finance industry, companies newly going public or have missing data were deleted. Then we deleted companies with identity or the share ratio of the largest shareholder changing ${ }^{6}$ in one accounting year to minimize the effects of ownership change on related party transactions. Finally, we deleted the sample whose share ratio of the largest shareholder equals to what of the second largest shareholder to weaken the effects of co-control. Then, our sample consists of 1643 firm-year observations. The descriptive statistics are shown in Table 2.

\footnotetext{
${ }^{6}$ When the control rights transfer, the original law of the related party transactions is affected by the changing of the benefits relationship. But there are two possibilities different from the general status: the ultimate controller of the listed company maybe still the same one while the direct controlling shareholder changes, the controlling shareholders before and after are related. These two possibilities are quite rare and difficult to observe for outsiders, so we delete all the data whose controlling shareholders changed.
} 
Table 2 Descriptive statistics

\begin{tabular}{lccccc}
\hline \multicolumn{1}{c}{ Variables } & $N$ & Minimum & Maximum & Mean & Std. Deviation \\
\hline$R_{i, t}$ & & 0.1563 & 2.6009 & 0.8152 & 0.1895 \\
$E P S_{i, t} / P_{i, t-1}$ & & -0.5803 & 0.0856 & 0.0043 & 0.0265 \\
CS $_{i, t-1}$ & 1643 & 0.0373 & 0.8500 & 0.4530 & 0.1737 \\
Second $_{i, t-1}$ & & 0.0001 & 0.3739 & 0.0807 & 0.0835 \\
Third $_{i, t-1}$ & & 0.0001 & 0.2475 & 0.0309 & 0.0367 \\
RPT $_{i, t}$ & & 0.0000 & 1.0000 & 0.4763 & 0.4996 \\
\hline
\end{tabular}

Table 2 indicates that the share ratio of the largest shareholder is ranging from $3.73 \%$ to $85 \%$. Mean is $45.30 \%$, reflecting the strong control of the largest shareholder. The maximum of the second largest shareholder is $37.39 \%$, but mean is only $8.07 \%$ representing a limited balance mechanism. Mean of the related party transactions is nearly 0.5 , indicating the universality of related party transactions in Chinese listed companies. So, it is very important to research on the relationship among controlling shareholders, related party transactions and earnings quality.

\subsection{Mediation tests}

We divided the 1643 firm-year observations into two groups with the dividing line of absolutely control right by the largest shareholder (with a share ratio of $50 \%^{7}$ ) to run regression.

\subsubsection{Results of model 1}

Table 3 Results of model 1

\begin{tabular}{|c|c|c|c|c|}
\hline & Expectation & 2001 & 2002 & Pooled \\
\hline Panel A $C S_{i, t-1} \leq 50 \%$ & & & & \\
\hline Intercept & ? & $\begin{array}{c}0.833 * * * \\
(4.203)\end{array}$ & $\begin{array}{c}-0.924 * * * \\
(-3.987)\end{array}$ & $\begin{array}{r}0.719 * * * \\
(29.472)\end{array}$ \\
\hline$E P S_{i, t} / P_{i, t-1}$ & + & $\begin{array}{c}6.754 * * * \\
(3.735) \\
\end{array}$ & $\begin{array}{l}3.283^{* *} \\
(2.523) \\
\end{array}$ & $\begin{array}{c}5.183^{* * *} \\
(4.832)\end{array}$ \\
\hline
\end{tabular}

\footnotetext{
${ }^{7}$ According to prior literature, there is a inverted-U-shaped relationship between the share ratio of the largest shareholder and some management results, the turning point often appears around 50\% (such as Li et al., 2004). This paper tested the impact of the share ratio change of the largest shareholder on the basic ERC. In univariate and multivariate analyses, we found strong evidence of the $50 \%$ share ratio as a dividing line. The analyses results are not reported here due to space limitation.
} 


\begin{tabular}{|c|c|c|c|c|}
\hline & & & & (Continued \\
\hline & Expectation & 2001 & 2002 & Pooled \\
\hline$E P S_{i, t} / P_{i, t-1} * C S_{i, t-1}$ & - & $\begin{array}{c}-0.135^{* * *} \\
(-2.798)\end{array}$ & $\begin{array}{c}-0.046 \\
(-1.313)\end{array}$ & $\begin{array}{c}-0.084 * * * \\
(-2.886)\end{array}$ \\
\hline$L e v_{i, t}$ & $?$ & $\begin{array}{l}-0.033 \\
(-0.747)\end{array}$ & $\begin{array}{c}-0.093 * * * \\
(-3.915)\end{array}$ & $\begin{array}{c}-0.036^{* *} \\
(-2.026)\end{array}$ \\
\hline Size $_{i, t}$ & $?$ & $\begin{array}{c}0.006 \\
(0.477)\end{array}$ & $\begin{array}{c}0.081 * * * \\
(7.449)\end{array}$ & $\begin{array}{c}0.004 * * * \\
(3.178)\end{array}$ \\
\hline Beta $_{i, t}$ & $?$ & $\begin{array}{c}-0.117 * * * \\
(-3.619)\end{array}$ & $\begin{array}{c}-0.002 \\
(-1.478)\end{array}$ & $\begin{array}{l}-0.001 \\
(-0.036)\end{array}$ \\
\hline$Q_{i, t}$ & $?$ & $\begin{array}{c}0.013 \\
(0.692)\end{array}$ & $\begin{array}{c}0.069 * * * \\
(5.727)\end{array}$ & $\begin{array}{c}0.024 * * * \\
(3.128)\end{array}$ \\
\hline $\operatorname{Adj} R^{2}$ & & 0.096 & 0.172 & 0.085 \\
\hline$F$ & & $8.255^{* * *}$ & $19.197 * * *$ & $15.561^{* * *}$ \\
\hline \multicolumn{5}{|l|}{ Panel B $C S_{i, t-1}>50 \%$} \\
\hline Intercept & $?$ & $\begin{array}{c}0.973 * * * \\
(6.330)\end{array}$ & $\begin{array}{c}-1.148 * * * \\
(-4.021)\end{array}$ & $\begin{array}{c}0.855^{* * *} \\
(17.520)\end{array}$ \\
\hline$E P S_{i, t} / P_{i, t-1}$ & + & $\begin{array}{c}0.845^{* * *} \\
(2.622)\end{array}$ & $\begin{array}{c}0.623 * * * \\
(2.633)\end{array}$ & $\begin{array}{c}0.784 * * * \\
(3.897)\end{array}$ \\
\hline$E P S_{i, t} / P_{i, t-1} * C S_{i, t-1}$ & + & $\begin{array}{c}0.010 * * \\
(2.180)\end{array}$ & $\begin{array}{c}0.015 * * * \\
(3.833)\end{array}$ & $\begin{array}{c}0.017 * * * \\
(5.128)\end{array}$ \\
\hline$L e v_{i, t}$ & $?$ & $\begin{array}{l}0.047^{*} \\
(1.374)\end{array}$ & $\begin{array}{c}0.040 * * \\
(1.930)\end{array}$ & $\begin{array}{c}0.388^{* *} \\
(2.152)\end{array}$ \\
\hline Size $_{i, t}$ & $?$ & $\begin{array}{l}-0.005 \\
(-0.445)\end{array}$ & $\begin{array}{c}0.923 * * * \\
(7.552)\end{array}$ & $\begin{array}{c}0.005 * * * \\
(3.438)\end{array}$ \\
\hline$B e t a_{i, t}$ & $?$ & $\begin{array}{c}-0.171 * * * \\
(-5.315)\end{array}$ & $\begin{array}{c}-0.729 * * \\
(-2.044)\end{array}$ & $\begin{array}{c}-0.154 * * * \\
(-6.093)\end{array}$ \\
\hline$Q_{i, t}$ & $?$ & $\begin{array}{l}0.042 * * \\
(2.272)\end{array}$ & $\begin{array}{c}0.088^{* * * *} \\
(3.366)\end{array}$ & $\begin{array}{l}0.024^{*} \\
(1.610)\end{array}$ \\
\hline $\operatorname{Adj} R^{2}$ & & 0.134 & 0.246 & 0.150 \\
\hline$F$ & & $9.262 * * *$ & $21.748 * * *$ & $21.643 * * *$ \\
\hline
\end{tabular}

Notes:

(1) *** significant at 0.01 level (two tailed test), ** significant at 0.05 level, * significant at 0.1 level.

(2) The results of year and industry are omitted.

Table 3 shows the results of Model 1 . The coefficient of the share ratio of the largest shareholder in group 1 is significant -0.084 at 0.01 level (panel A), which reduces the basic ERC. That is to say, there is a significantly negative relationship between the share ratio of the largest shareholder and earnings quality.

We used ridge regression with ridge parameters $k_{2001}=0.12, k_{2002}=0.08$, 
$k_{\text {pool }}=0.08$ in group 2 to eliminate Multi-Collinearity ${ }^{8}$ (panel B). The results showed that when the share ratio of the biggest shareholder is over $50 \%$, there is a significant positive relationship between the share ratio and earnings quality.

In addition, the controlled variables represented consistent characteristics in both groups: size is positively related with market return, $\beta$ is negatively related with market return, $Q$ has a positive relationship with market return, reflecting clear market expectations of corporate size, risk and growth. By comparison, debt ratio is different. There is a negative relationship in group 1 and a positive one in group 2. A possible explanation is that a share ratio exceeding $50 \%$ of the largest shareholder means a closer relationship between the shareholder and the corporation. The debt size represents an optimistic expectation of the insiders and gives a good signal to the outsiders.

\subsubsection{Results of Model 2}

Since we took related party transactions as the mediator, we need to know if related party transactions are affected by the largest shareholder. The results of Model 2 are shown in Table 4. The share ratio of the largest shareholder is positively related to related party transactions in both groups. Related party transactions are important ways to pursue the benefits of control. There is a weak balance effect from the second and the third largest shareholders in group 1. In group 2, the second largest shareholder also enjoys related party transactions, which infers that the largest shareholder is apt to creating shared benefits.

Table 4 Results of Model 2

\begin{tabular}{lcccc}
\hline \multicolumn{1}{c}{ Variable } & Expectation & 2001 & 2002 & Pooled \\
\hline Panel A $C S_{i, t-1} \leq 50 \%$ & & & & \\
& & $-2.699 * * *$ & $-1.408 * * *$ & $-1.871 * * *$ \\
Intercept & $?$ & $(22.417)$ & $(10.966)$ & $(32.216)$ \\
& & $0.051 * * *$ & $0.057 * * *$ & $0.051 * * *$ \\
$C S_{i, t-1}$ & + & $(13.783)$ & $(28.206)$ & $(40.188)$ \\
Second & & 0.017 & -0.018 & -0.002 \\
& - & $(1.502)$ & $(2.427)$ & $(0.053)$ \\
Third & & -0.056 & $-0.059 * *$ & $-0.057 * * *$ \\
$N$ & - & $(2.466)$ & $(4.611)$ & $(7.165)$ \\
Cox \& Snell $R^{2}$ & & 413 & 527 & 940 \\
& & 0.062 & 0.110 & 0.081 \\
\hline
\end{tabular}

\footnotetext{
${ }^{8}$ Although ridge regression is biased, it is more stable than OLS and could avoid Multi-Collinearity in OLS.
} 


\begin{tabular}{|c|c|c|c|c|}
\hline Variable & Expectation & 2001 & 2002 & Pooled \\
\hline Nagelkerke $R$ Square & & 0.090 & 0.147 & 0.110 \\
\hline Panel B $C S_{i, t-1}>50 \%$ & & & & \\
\hline Intercept & $?$ & $\begin{array}{c}-2.172 * * \\
(4.517)\end{array}$ & $\begin{array}{c}-2.562 * * \\
(5.800)\end{array}$ & $\begin{array}{c}-1.898 * * * \\
(7.308)\end{array}$ \\
\hline$C S_{i, t-1}$ & + & $\begin{array}{c}0.030 * * \\
(3.964)\end{array}$ & $\begin{array}{c}0.054 * * * \\
(10.720)\end{array}$ & $\begin{array}{c}0.035 * * * \\
(10.755)\end{array}$ \\
\hline Second $_{i, t-1}$ & + & $\begin{array}{c}0.038 \\
(2.469)\end{array}$ & $\begin{array}{c}0.042 \\
(2.528)\end{array}$ & $\begin{array}{c}0.037 * * \\
(4.591)\end{array}$ \\
\hline Third $_{i, t-1}$ & + & $\begin{array}{l}-0.081 \\
(0.557)\end{array}$ & $\begin{array}{l}-0.002 \\
(0.000)\end{array}$ & $\begin{array}{l}-0.031 \\
(0.207)\end{array}$ \\
\hline$N$ & & 321 & 383 & 704 \\
\hline Cox \& Snell $R^{2}$ & & 0.020 & 0.033 & 0.020 \\
\hline Nagelkerke $R^{2}$ & & 0.026 & 0.048 & 0.027 \\
\hline
\end{tabular}

Notes:

(1) Wald results are in brackets, $* * *$ significant at 0.01 level (two tailed test), ** significant at 0.05 level, * significant at 0.1 level.

(2) The results of year and industry are omitted.

\subsubsection{Results of Model 3}

We need Model 3 to finish the mediation test and results are exhibited in Table 5. Panel A shows the results of group 1. The coefficient of related party transactions is significantly negative which means a negative effect on earnings quality. The coefficient of the share ratio of the largest shareholder is still significant but weaker than the corresponding result in Table 3. Panel B shows a significantly positive relationship between related party transactions and earnings quality. The results of shareholder are the same with Panel A. We can thus infer a partial mediation effect existing. To confirm whether these results are statistically significant, we used the method of Freedman and Schatzkin (1992) and computed the result of coefficient of the share ratio of the largest shareholder in Model 1 minus what in Model 3. Then we compared this result by using the formula as below:

$$
t_{N-2}=\frac{\lambda-\lambda^{\prime}}{\sqrt{\sigma_{\lambda}^{2}+\sigma_{\lambda^{\prime}}^{2}-2 \sigma_{\lambda} \sigma_{\lambda^{\prime}} \sqrt{1-\rho_{X M}^{2}}}}
$$

$\sigma_{\lambda}$ is the std. deviation of $\lambda, \sigma_{\lambda^{\prime}}$ the std. deviation of $\lambda^{\prime}, \rho_{X M}$ the correlation coefficient of the share ratio of the largest shareholder and related 
party transactions.

$T$ of the pooled data is -2.513 in Group 1, 13.153 in Group 2, which means the coefficient of the share ratio is significantly reduced, indicating that related party transactions are a mediator between controlling shareholders and earnings quality.

Table 5 Results of Model 3

\begin{tabular}{|c|c|c|c|c|}
\hline & Expectation & 2001 & 2002 & Pooled \\
\hline \multicolumn{5}{|l|}{ Panel A $C S_{i, t-1} \leq 50 \%$} \\
\hline Intercept & $?$ & $\begin{array}{c}0.805 * * * \\
(4.494)\end{array}$ & $\begin{array}{c}0.291 * * * \\
(3.937)\end{array}$ & $\begin{array}{c}0.716^{* * * *} \\
(29.323)\end{array}$ \\
\hline$E P S_{i, t} / P_{i, t-1}$ & + & $\begin{array}{c}5.139 * * * \\
(3.606)\end{array}$ & $\begin{array}{c}3.417 * * * \\
(3.025)\end{array}$ & $\begin{array}{c}4.988 * * * \\
(4.631)\end{array}$ \\
\hline$E P S_{i, t} / P_{i, t-1} * C S_{i, t-1}$ & - & $\begin{array}{c}-0.078 * * \\
(-2.132)\end{array}$ & $\begin{array}{c}-0.039 \\
(-1.287)\end{array}$ & $\begin{array}{c}-0.062 * * \\
(-1.973)\end{array}$ \\
\hline$E P S_{i, t} / P_{i, t-1} * R P T_{i, t}$ & - & $\begin{array}{l}-0.938 * \\
(-1.618)\end{array}$ & $\begin{array}{l}-1.170 * \\
(-1.694)\end{array}$ & $\begin{array}{l}-1.048^{*} \\
(-1.754)\end{array}$ \\
\hline$L e v_{i, t}$ & $?$ & $\begin{array}{c}-0.025 \\
(-0.640)\end{array}$ & $\begin{array}{c}-0.088 * * * \\
(-4.161)\end{array}$ & $\begin{array}{l}-0.035^{*} \\
(-1.940)\end{array}$ \\
\hline Size $_{i, t}$ & $?$ & $\begin{array}{c}0.009 \\
(0.764)\end{array}$ & $\begin{array}{c}0.046 * * * \\
(6.966)\end{array}$ & $\begin{array}{c}0.004 * * * \\
(3.266)\end{array}$ \\
\hline Beta $_{i, t}$ & $?$ & $\begin{array}{c}-0.138^{* * *} \\
(-4.696)\end{array}$ & $\begin{array}{c}-0.002 \\
(-1.541)\end{array}$ & $\begin{array}{l}-0.000 \\
(-0.008)\end{array}$ \\
\hline$Q_{i, t}$ & $?$ & $\begin{array}{l}0.031^{*} \\
(1.740)\end{array}$ & $\begin{array}{c}0.059 * * * \\
(5.606)\end{array}$ & $\begin{array}{c}0.024 * * * \\
(3.138)\end{array}$ \\
\hline $\operatorname{Adj} R^{2}$ & & 0.095 & 0.154 & 0.087 \\
\hline$F$ & & $7.169^{* * *}$ & $17.103^{* * *}$ & $13.808^{* * *}$ \\
\hline \multicolumn{5}{|l|}{ Panel B $C S_{i, t-1}>50 \%$} \\
\hline Intercept & $?$ & $\begin{array}{c}0.963 * * * \\
(6.285)\end{array}$ & $\begin{array}{c}-1.016^{* * *} \\
(3.937)\end{array}$ & $\begin{array}{c}0.853 * * * \\
(17.558)\end{array}$ \\
\hline$E P S_{i, t} / P_{i, t-1}$ & + & $\begin{array}{c}1.045^{* * *} \\
(3.508)\end{array}$ & $\begin{array}{l}0.531 * * \\
(2.212)\end{array}$ & $\begin{array}{c}0.636 * * * \\
(3.033)\end{array}$ \\
\hline$E P S_{i, t} / P_{i, t-1} * C S_{i, t-1}$ & + & $\begin{array}{l}0.012 * * \\
(2.340)\end{array}$ & $\begin{array}{l}0.008 * * \\
(2.105)\end{array}$ & $\begin{array}{c}0.012 * * * \\
(3.448)\end{array}$ \\
\hline$E P S_{i, t} / P_{i, t-1} * R P T_{i, t}$ & + & $\begin{array}{c}0.588 \\
(1.066)\end{array}$ & $\begin{array}{c}1.727 * * * \\
(3.541)\end{array}$ & $\begin{array}{c}1.271 * * * \\
(3.312)\end{array}$ \\
\hline$L e v_{i, t}$ & $?$ & $\begin{array}{l}0.049 * \\
(1.366)\end{array}$ & $\begin{array}{c}0.040 * * \\
(1.970)\end{array}$ & $\begin{array}{c}0.037 * * \\
(2.096)\end{array}$ \\
\hline Size $_{i, t}$ & $?$ & $\begin{array}{c}0.004 \\
(0.378)\end{array}$ & $\begin{array}{c}0.085^{* * *} * \\
(7.005)\end{array}$ & $\begin{array}{c}0.004 * * * \\
(3.060)\end{array}$ \\
\hline Beta $_{i, t}$ & $?$ & $\begin{array}{c}-0.174 * * * \\
(-5.386)\end{array}$ & $\begin{array}{c}-0.061 * * \\
(-1.717)\end{array}$ & $\begin{array}{c}-0.144 * * * \\
(-5.676)\end{array}$ \\
\hline
\end{tabular}




\begin{tabular}{lcccc}
\hline & \multicolumn{3}{c}{ (Continued) } \\
\hline$Q_{i, t}$ & Expectation & 2001 & 2002 & Pooled \\
${\text { Adj } R^{2}}^{*} ?$ & $0.044^{* * *}$ & $0.080^{* * *}$ & $0.022^{*}$ \\
$F$ & & $(2.367)$ & $(3.129)$ & $(1.518)$ \\
\hline
\end{tabular}

Notes:

(1) *** significant at 0.01 level (two tailed test), ** significant at 0.05 level, * significant at 0.1 level.

(2) Panel B uses ridge regression, ridge characters are $k_{2001}=0.12, k_{2002}=0.08, k_{\text {pool }}=0.08$ respectively.

(3) The results of year and industry are omitted.

\section{Conclusions and limitations}

This paper found a mediating effect of related party transactions between controlling shareholders and earnings quality.

\subsection{Conclusions}

When the share ratio is low, controlling shareholders are likely to pursue private benefits of control by related party transactions. As a result, earnings quality will be reduced. Related party transactions can be completed quickly within the control scope of controlling shareholders and could facilitate the interests distribution among controlling shareholders. The related party transactions based on private benefits are often characterized by profits adjusting, earnings management and so on, which are unfair to other minor shareholders and usually lead to low earnings quality.

When the ratio is high, related party transactions are usually aimed at obtaining shared benefits of control. As a result, earnings quality is improved. When the share ratio of controlling shareholders exceeds the dividing line, controlling shareholders prefer getting benefits by enhancing enterprise value. In doing so, related party transactions are frequently used. Since the related party transactions aim at obtaining shared benefits under such circumstances, they are highly efficient and transaction-costs-saving. Accordingly, earnings quality gets improved.

\subsection{Limitations}

First, proxies we used for controlling shareholder and earnings quality are not comprehensive enough. Ideally, data should come from field investigation in 
every listed company. Due to the limitations of time and funds, we were unable to do so. Instead, we used ERC as a substitute index to measure earnings quality.

Second, we ignored the time of initial announcement of related party transactions. In reality, some information of related party transactions is absorbed by the market when announced. In addition, the effects of the annual report do not owe to related party transactions completely. We thus can not eliminate completely effects of other non-controlled factors.

Since time period was not long enough, we only collected data of Chinese listed companies in 2001 and 2002. Therefore, the applicability of the conclusions needs to be further proved.

Acknowledgements This work is supported by the National Natural Science Foundation of China (Grant No. 70572096).

\section{References}

Aghion P, Bolton $\mathrm{P}(1992)$. An incomplete contract approach to financial contracting. Review of Economic Studies, 59: 473-494

Baron R M, Kenny D A(1986). The moderator-mediator variable distinction in social psychological research: Conceptual, strategic, and statistical considerations. Journal of Personality and Social Psychology, 51: 1173-1182

Chang S J(2003). Ownership structure, expropriation, and performance of group-affiliated companies in Korea. Academy of Management Journal, 46(2): 238-253

Chen Xiao, Wang Kun(2005). Related party transactions, corporate governance and state ownership reform. Economic Research Journal, (4): 77-86 (in Chinese)

Cheung Yan-Leung, Rau P R, Stouraitis A(2004). Tunneling, propping and expropriation: Evidence from connected party transactions in Hong Kong. SSRN Working Paper

Coase R H(1937). The Firm, the Market and the Law. Chicago: University of Chicago Press

Dyck A, Zingales L(2004). Private benefits of control: an international comparison. The Journal of Finance, 59(2): 537-600

Fan J P H, Wong T J(2002). Corporate ownership structure and the informativeness of accounting earnings in East Asia. Journal of Accounting and Economics, 33: 401-425

Freedman L S, Schatzkin A(1992). Sample size for studying intermediate endpoints within intervention trials of observational studies. American Journal of Epidemiology, 136: $1148-1159$

Gilson R J, Gordon J N(2003). Controlling shareholders. SSRN Working Paper

Gordon E A, Henry E(2003). Related party transactions and earnings management. SSRN Working Paper

Harris M, Raviv A(1988). Corporate governance: Voting rights and majority rules. Journal of Financial Economics, 20: 203-235

Hayn C(1995). The information content of losses. Journal of Accounting and Economics, 20: 123-153

Holderness C G(2003). A survey of blockholders and corporate control. Economic Policy Review, 9(1): 51-63

Hong Jianqiao, Fang Junxiong(2005). The value relevance of related party transactions and 
earnings. China Accounting Review, 3(1): 87-98 (in Chinese)

Huang Shizhong(2001). Challenges to the quality of accounting information of listed companies. Accounting Research, 10: 6-11 (in Chinese)

Jian M, Wong $\mathrm{T} \mathrm{J}(2004)$. Earnings management and tunneling through related party transactions: Evidence from Chinese corporate groups. SSRN Working Paper

Li Zengquan, Sun Zheng, Wang Zhiwei(2004). Tunneling and ownership structure of a firm: Evidence from controlling shareholder's embezzlement of listed company's funds in China. Accounting Research, (12): 3-13 (in Chinese)

MacKinnon D P, Lockwood C M, Hoffman J M, West S G, Sheets V(2002). A comparison of methods to test mediation and other intervening variable effects. Psychological Methods, 7(1): 83-104

Mikkelson W, Ruback R S(1985). An empirical analysis of the interfirm equity investment process. Journal of Financial Economics, (14): 523-553

Shaver J M(2005). Testing for mediating variables in management research concerns, implications and alternative strategies. Journal of Management, 31(3): 330-353

Shleifer A, Vishny R W(1986). Large shareholders and corporate control. Journal of Political Economy, 95: 461-488

Sun Yongxiang, Huang Zuhui(1999). Ownership structure and performance of the listed companies. Economic Research Journal, (2): 23-50 (in Chinese)

Wang Huacheng, Tong Yan(2006). Controlling shareholders and earnings quality. Accounting Research, (2): 66-74(in Chinese)

Yu Minggui, Xia Xinping(2004). Controlling shareholder, agency problem and related party transaction: Evidence from China's listed companies. Nankai Business Review, 7(6): 56-61 (in Chinese) 